\title{
Some Aspects of Importance of Environment Friendly Logistics
}

\author{
Romana Hricová ${ }^{1}$, Vladimir Duchek ${ }^{2}$, Milan Edl ${ }^{2}$ \\ \{romana.hricova@tuke.sk, duchekv@kto.zcu.cz, edl@kpv.zcu.cz \}
}

Technical University of Kosice, Faculty of Manufacturing Technologies with a seat in Presov, Department of Industrial Engineering and Informatics, Bayerova 1, 08001 Presov, Slovakia ${ }^{1}$ University of West Bohemia, Faculty of Mechanical Engineering, Univerzitní 8, 30100 Pilsen, Czech Republic $^{2}$

\begin{abstract}
The article deals with very topical problems as nowadays environment protection is very actual and one of the most obvious areas is freight transport, because it is an important creator of greenhouse gas and environment pollution. Countries face to big public pressure to decrease negative ecological but also economical and social impacts of freight transport. The aim of the article is also showing how to deal with improving of environmental performance of freight transport as there are many ways how to reduce carbon dioxide $\left(\mathrm{CO}_{2}\right)$ in international road and rail freight transport. Generally actions could be divided to technical and non-technical measures.
\end{abstract}

Keywords: freight transport, greenhouse gas, emission, green logistics

\section{Introduction}

Our society is highly mobile as a result of globalization, which brings with itself an increase in the international transport of goods between countries and continents. The European Commission introduced within the Transport White Paper interesting roadmap for the future of transport until 2050 in the year 2011. Huge changes in the road freight transport push to the increase of environmental, reliable and efficient transport system. Plus freight transport is an important environment's contributor of the pollution and impacts the environment in various ways including the greenhouse effect, toxic effects on ecosystems, toxic effects on humans, land use (by infrastructure such as roads), noise, and resource consumption [1] Different modes of transport emit varying amounts of greenhouse gases, [2] for example, estimates the $\mathrm{CO}_{2}$ content of gasoline and diesel to be $2.32 \mathrm{~kg} / \mathrm{L}$ and $2.67 \mathrm{~kg} / \mathrm{L}$, respectively. For electrically powered vehicles, emissions depend on how the electricity is generated, varying from burning coal to watercraft. [3]

On the other hand heavy duty vehicles were responsible for around 30\% of road transport emissions, that is, more than 5\% of EU Greenhouse Gas (GHG) emissions. This implies that less than $5 \%$ of all vehicles on the road emit around $30 \%$ of road transport $\mathrm{CO}_{2}$ emissions. Moreover, forecasts for this highly polluting mode are negative: Heavy duty vehicles emissions are projected to rise $22 \%$ by 2030 . [4]

Slovak republic as well as many other advanced countries is facing to big pressure to make greener the freight transport logistics. Good news is, that in 2015, greenhouse gas emissions in the EU-28 were down by $22 \%$ compared with 1990 levels, representing an absolute reduction of 1265 million tonnes of $\mathrm{CO}_{2}$-equivalents, putting the EU on track to 
surpass its 2020 target, which is to reduce greenhouse gas (GHG) emissions by $20 \%$ by 2020 and by $40 \%$ by 2030 compared with 1990. [5]

\section{Modal split in the EU-28}

Every production unit that wants to be competitive in the present day should be characterized by a suitable combination of needed productivity, flexibility and quality. [6]

But the production efficiency is not only aspect that is necessary to consider when the company wants to develop. It is advantageous to think in several steps forward and incorporate all aspects of production process into the plans and management decisions. One of the issues that influence a product price is a transportation of semiproducts/row materials and final products. [7,8] Transport is thus an important aspect of competitiveness, and at the same time an instrument of competitive struggle, because the environmental aspect is getting to the forefront.

The largest share of EU freight transport has road transport among the three inland transport modes (rail, inland waterways, and road transport). Road transport accounted for over $3 / 4$ (around $75 \%$ ) of the total inland freight transport and the share is stable, fluctuating between 74,7\% (lowest value in 2012) and 76,4\% (highest value in 2016) as shows Figure 1. [9]

The modal split between the different modes of transport is without huge changes for several last years, but national statistics show that changes are more noticeable in individual countries.

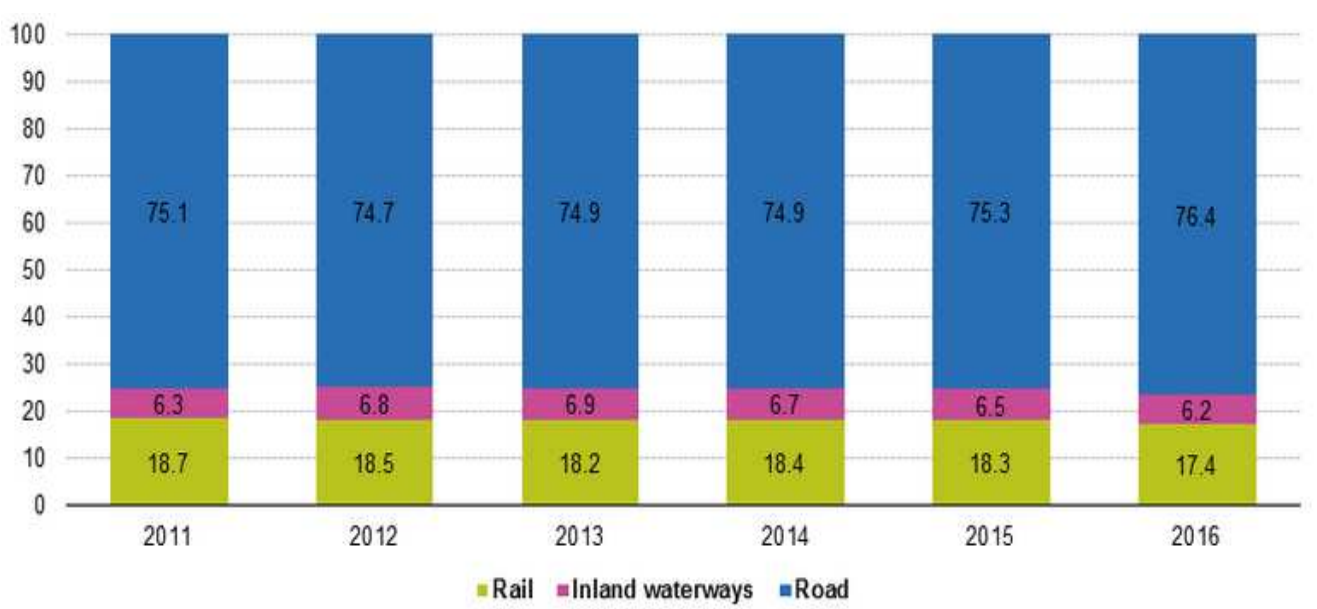

Fig. 1. Freight transport in the EU-28: modal split of inland transport modes (\% of total tonnekilometres) [9]

Total inland transport increase and as Table 1 shows in the period 2011-2016 growth was almost 100 billion tonne-kilometres in EU-28. 
Table 1. Transport performance of inland modes (million tkm) in EU-28 [9]

\begin{tabular}{|c|c|c|c|c|}
\hline Year & Rail & Inland waterways & Road & Total \\
\hline 2011 & 422097 & 141969 & 1699186 & $\mathbf{2 2 6 3 2 5 2}$ \\
\hline 2015 & 415644 & 147471 & 1714323 & $\mathbf{2 2 7 7 4 3 8}$ \\
\hline 2016 & 411284 & 147317 & 1803523 & $\mathbf{2 ~ 3 6 2 ~ 1 2 4}$ \\
\hline
\end{tabular}

But inland transport brings cost which can be divided into internal and external cost. Taking only freight transport, internal cost (sometimes referred to as marker or private costs) are the costs borne directly by road freight transport operators.

Internal costs include: [10]

- operating costs (closely related to the level of haulage activity and include fuel, repair and maintenance, human labour, taxes, depreciation, infrastructure charges, insurance etc. )

- capital investments in facilities and vehicles.

\section{External costs}

are externalities (Table 2) which are carrying over from the road freight traffic to the society as a whole. This is a reason why externalities are not taken into account by transport users normally. These costs are paid by public, not by their originator as logistics or transport operators, manufacturers, producers, etc.

Because of these facts, there is enormous public pressure for more effective ecological regulations for the market players and not only to the social and environmental impacts of trade, but it is also political question.

Table 2. Freight transport externalities [11]

\begin{tabular}{|l|l|}
\hline Category & Externality \\
\hline Ecological impacts & 1) Air pollutant as for example Carbon monoxide, Nitrogen \\
& oxides, Hydrocarbons, Sulphur dioxide... \\
& 2) Greenhouse gases cause climate change \\
& 3) Low recycling of waste products such as tires and oil \\
& 4) The use of non-renewable fossil fuel \\
5) Destruction of local ecosystems and extinction of species
\end{tabular}




\section{Freight transport and its relation to the environment}

Environmental aspects play big role in decision analyses, at which many other aspects are usually necessary to take into account, but the optimization criteria considering the pollution have a great robustness and effect on the final decision very much. [12]

New technologies in all fields of industry are developed today that try to be environmentally friendly. However, not just the technology itself, but also the testing conditions, equipment used during the experiments, as well as the waste material processing are set in the way to be favorable to the global environment including logistics. [13]

The European Union supports the global effort to decrease and reduce GHG emissions. On 4th November 2016 entered into force Paris Agreement on climate change which central aim is to hold the increase in the global temperature to well below $2^{\circ} \mathrm{C}$ above pre-industrial levels and to pursue efforts to limit the temperature increase to $1.5^{\circ} \mathrm{C}$ above pre-industrial levels. [8]

Comparison of greenhouse gas emissions (by source) in 1990 and 2015 shows, that transport produces more greenhouse gas emissions.

Table 3. Greenhouse gas emissions, by source sector, EU-28 [14]

\begin{tabular}{|l|l|l|}
\hline Greenhouse gas emissions & 1990 & 2015 \\
\hline Waste management & $4 \%$ & $3 \%$ \\
\hline Agriculture & $10 \%$ & $10 \%$ \\
\hline Industrial processes and product use & $9 \%$ & $8 \%$ \\
\hline Transport (incl. international aviation) & $15 \%$ & $23 \%$ \\
\hline $\begin{array}{l}\text { Fuel combustion and fugitive emissions } \\
\text { from fuel (without transport) }\end{array}$ & $62 \%$ & $55 \%$ \\
\hline
\end{tabular}

Table 3 also clearly shows that only one sector is with negative environmental trends transport. Opposite to the other sectors, only transport's GHG emissions are higher from 1990 to 2015. On the other hand, next sectors were able to decrease, slow or stop the trend of increasing emissions. This is one of the main reasons, why EU tries to solve the situation and give high accent on railway cargo transport. Because of it, member states are obligated to make liberal reforms of their national rail freight transport and promote modal shift from roads to rails.

More than $60 \%$ of freight transport in EU28 is done via road. Comparison of the $\mathrm{CO}_{2}$ emissions of freight transport shows that road trucks and aircraft have significantly worse impacts as waterways and railways as is seen in Figure 2.

Trains appear to be a medium with a low carbon footprint; diesel trains have very low $\mathrm{CO}_{2}$ emissions even though increasing their efficiency is not very much on the "program of the day". On the other hand, the efficiency of modern electric trains has much greater potential due to utilization of power electronics and regenerative braking although the effects are partly compensated by the increase of energy consumption thanks to higher speed. 


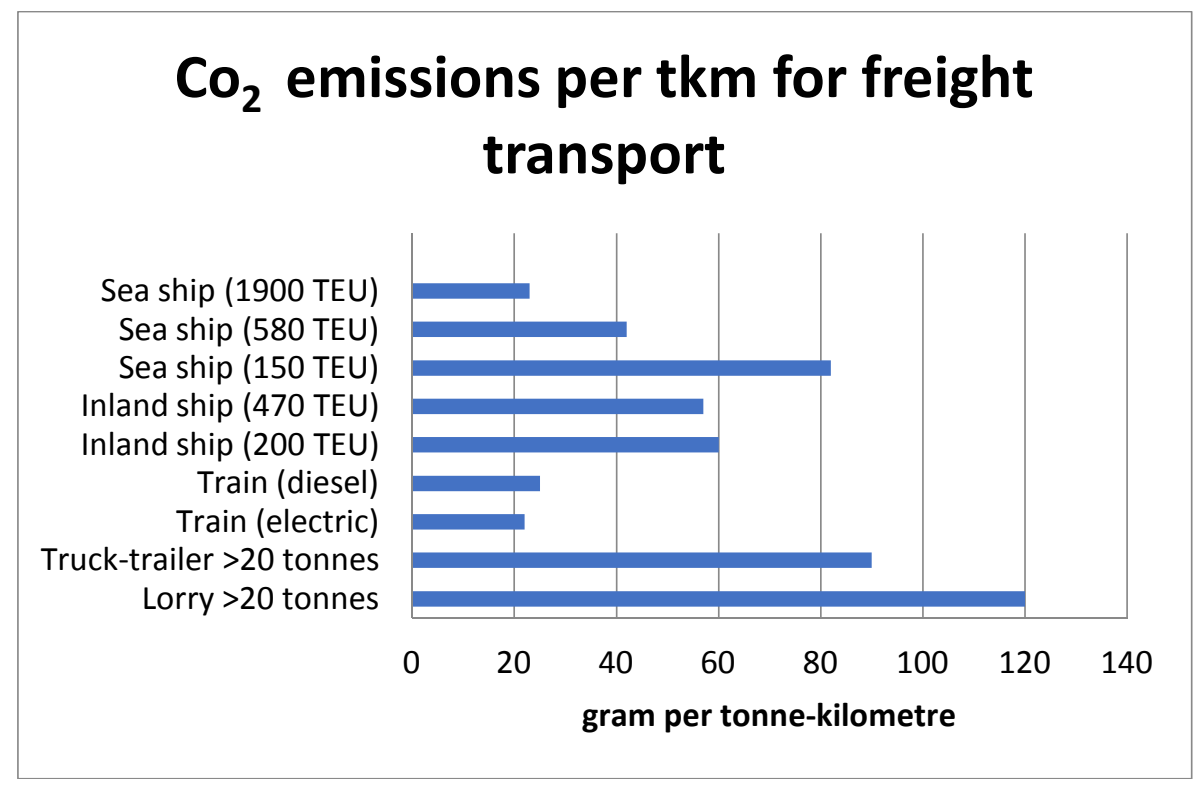

Fig. 2. $\mathrm{CO}_{2}$ emissions per tkm for freight transport

Table 4. Rank by share of total greenhouse gas emissions by countries in EU-28

\begin{tabular}{|l|l|l|}
\hline Rank by share & EU-28 country & Share \\
\hline 1. & Germany & $20,8 \%$ \\
\hline 2. & United Kingdom & $12,1 \%$ \\
\hline 3. & France & $10,7 \%$ \\
\hline 4. & Italy & $9,9 \%$ \\
\hline 5. & Poland & $8,7 \%$ \\
\hline 6. & Netherlands & $4,6 \%$ \\
\hline 7. & Czech republic & $2,9 \%$ \\
\hline 8. & Belgium & $2,7 \%$ \\
\hline 9. & Romania & $2,6 \%$ \\
\hline 10. & Greece & $2,2 \%$ \\
\hline 11. & Austria & $1,8 \%$ \\
\hline 12. & Portugal & $1,6 \%$ \\
\hline 13. & Bulgaria, Ireland, Hungary & $1,4 \%$ \\
\hline 14. & Finland, Sweden & $1,3 \%$ \\
\hline 15. & Denmark & $1,1 \%$ \\
\hline 16. & Slovakia & $0,9 \%$ \\
\hline 17. & Croatia, Lithuania & $0,5 \%$ \\
\hline 18. & Estonia, Slovenia & $0,4 \%$ \\
\hline 19. & Latvia, Luxembourg & $0,3 \%$ \\
\hline 20. & Cyprus & $0,2 \%$ \\
\hline 21. & Malta & $0,1 \%$ \\
\hline
\end{tabular}


Table 5 shows clear and perfect evidence of health and environmental effects of the biggest air pollutants.

Table 5. Health and environmental effects of air pollutant and greenhouse gas from freight transport [11]

\begin{tabular}{|c|c|}
\hline $\begin{array}{l}\text { Air pollutant/greenhouse } \\
\text { gas }\end{array}$ & Health/environmental effects \\
\hline Carbon dioxide $\mathrm{CO}_{2}$ & $\begin{array}{l}\mathrm{CO}_{2} \text { is an asphyxiant gas and although it is not classified as toxic or harmful, it } \\
\text { is very important greenhouse gas. Its concentration has increased by about } 35 \% \\
\text { from the beginning of industrialization. Contributes to global warming. }\end{array}$ \\
\hline Carbon monoxide $\mathrm{CO}$ & $\begin{array}{l}\text { CO it is colorless, odorless and tasteless, but highly toxic and poisoning by CO } \\
\text { is the most common type of fatal air poisoning in many countries. It combines } \\
\text { with hemoglobin to produce carboxyhemoglobin, which usurps the space in } \\
\text { hemoglobin that normally carries oxygen to bodily tissues. In high } \\
\text { concentration can cause death, in low affect nervous system. }\end{array}$ \\
\hline Hydrocarbons & $\begin{array}{l}\text { Hydrocarbons are air pollutants as well as greenhouse gases. Can cause } \\
\text { respiration problems, skin irritation and in long term lung function impairment. } \\
\text { Hydrocarbons also create tropospheric ozone and contribute to global warming. }\end{array}$ \\
\hline Nitrogen oxides & $\begin{array}{l}\text { Both - air pollutants and greenhouse gases. Forms nitrous and nitric acid } \\
\text { contributes to eutrophication and acidification. Causes pulmonary problems and } \\
\text { is involved to creation of tropospheric ozone and contributes to global warming. }\end{array}$ \\
\hline Sulphur dioxide $\mathrm{SO}_{2}$ & $\begin{array}{l}\mathrm{SO}_{2} \text { is a toxic gas with a pungent, irritating smell. It is a major air pollutant and } \\
\text { has significant impacts upon human health. In addition, the concentration of } \\
\mathrm{SO}_{2} \text { in the atmosphere can influence the habitat suitability for plant } \\
\text { communities, as well as animal life. } \mathrm{SO}_{2} \text { emissions are a precursor to acid rain } \\
\text { and atmospheric particulates. }\end{array}$ \\
\hline Particulate matter & $\begin{array}{l}\text { Atmospheric aerosol particles, also known as atmospheric particulate matter, } \\
\text { particulate matter (PM), particulates, or suspended particulate matter (SPM) are } \\
\text { microscopic solid or liquid matter suspended in Earth's atmosphere. They affect } \\
\text { the climate of the earth by changing the amount of incoming solar radiation and } \\
\text { outgoing terrestrial long wave radiation retained in the earth's system. Causes } \\
\text { breathing problems and some constituents (eg . polyaromatic hydrocarbons) } \\
\text { may be carcinogenic }\end{array}$ \\
\hline
\end{tabular}

To shift freight transport from road to railways and waterways seems to be necessary because of positive environmental impacts. One of the strategies of European Union is to support intermodal freight transport. A request on healthy environment is topical and important for efficient transport. But the growing internationalization of commerce has broadened the concept of logistics to global logistics. Local environmental governance should support state efforts thru recommendations, implementations and operations occur at the local level because international trade is not more harmful to the environment that local or regional trade. There is strong need to promote a regional approach to green logistics as the main idea is not using more frequent and smaller shipments but vice versa to reduce the number of deliveries and to make model shift from road to railways or inland waterways if it is possible.

\section{Freight transport in Slovakia and its current problems}

There are several reasons, why the road freight transport is dominating, even more than public and government desire. Next subhead briefly describes the actual problems of individual modes of freight transport, mainly road and rail transports. Figure 3 shows goods transfer by freight transport in mil. tons between 2006 and 2014 


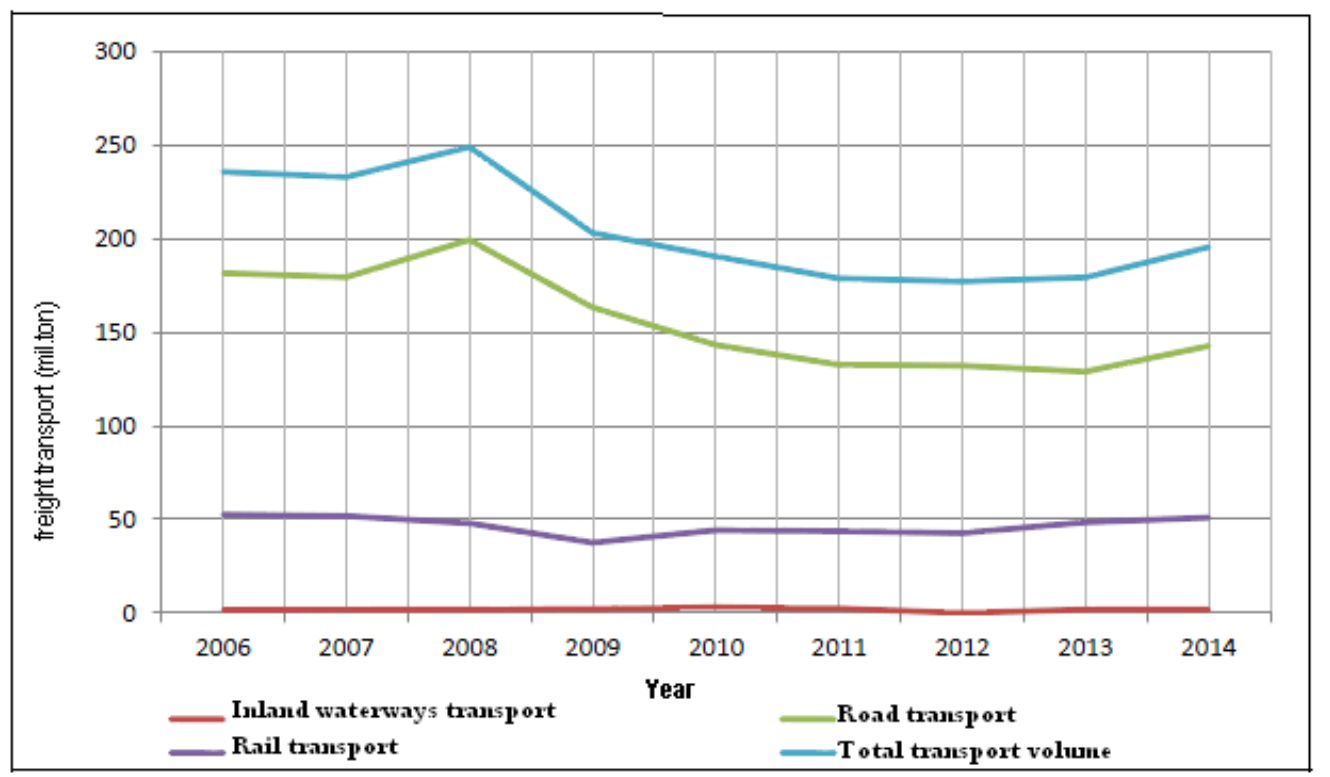

Fig. 3. Goods transfer by freight transport in mil. tons between 2006 and 2014

\subsection{Road freight transport}

The highest volume of freight transport is by road in Slovakia. Main reason is that road transport is more flexible in comparison with rail transport, which with decreased ability of rail companies to compete road transport have better chances to impressed the customers. On the other hand unequal pricing for transport infrastructure use was advantageous for a long time for road transport. When toll system of pricing was introduced (from January 1st 2010), it immediately caused strikes of some operators what showed that any pricing changes in very politically sensitive fields inhibits the reforming freight transport towards greener and more efficient. Finally, present situation in pricing is still more advantageous for road transport.

Main problems connected with road transport are:

- still unfinished infrastructure of motorways and expressways,

- bad quality and obsoleteness of $1^{\text {st }}$ class roads,

- insufficient capacity of existing roads,

- bottleneck in some nodes (for example near Žilina),

- safety issues,

- bypassing tolled sections by some operators thru parallel $2^{\text {nd }}$ and $3^{\text {rd }}$ class roads what damaging infrastructure very quickly,

- public protests against heavy lorries because of noise, houses damage by vibrations,

- accidents in some critical urban and transit areas,

- investments insufficient into infrastructure.

\subsection{Rail freight transport}

Approximately $1 / 5$ of total freight transport is made by rail freight transport. Railway infrastructure is insufficiently used because of obsolete (except of modernized corridor tracks) 
and with gradually degrading parameters (speeds, axle loads) so those make railway transport not accommodated to modern European rolling stocks. Corridor projects concentrate most of the investment and there is resignation to modernize other parts. State-owned rail companies still prove low effort to optimize from inside. However here is still exist significant market space for increase the ration of rail and intermodal freight transport.

\subsection{Inland waterway transport}

Only Danube waterway has importance for freight transport in Slovakia as part of corridor VII, AGN E80 which is navigable. There are three public ports on Danube in Slovakia (Bratislava, Komárno, Štúrovo), but only Bratislavian is commercially attractive at present time.

By connecting to the Danube, the Slovak Republic is directly connected via the RhineMain-Danube River to the international network of waterways of the 15 European countries. Southern connections are also heading to Greece, Turkey, and to the countries of the Near and Far East.

River Vah is not really navigable although its geographic position in the north-south orientation and its almost central location on the Danube-Mohan-Rhine trans-European waterway at its mouth of the Danube is a significant place on European transport corridors. The Standing Committee on Inland Navigation at the United Nations Economic Commission for Europe in Geneva assigned Vah waterway in 1995 to the list of future international voyages and assigned it the international identification code E81 with the recommended gauge of the International Voyage Class VIa and Sered' and Va after Žilina.

The connection to the Danube-Odra-Elbe waterway through the alternative route VáhMorava opens the possibility of direct connection of Slovakia with Baltic ports, but also integration into the network of waterways of Belarus, Ukraine and Russia.

The ships would reach Žilina by overtaking the fifteen sailing chambers. A possible connection to Odra would require more than fifteen shuttle chutes and ship lifts. Alternatively, when constructing a 2100-meter long overhead tunnel, a ship between Žilina and Bohumin would have to overcome about thirteen shuttle chambers and ship lifts.

\section{Perspective for improving environmental performance of freight transport}

As was presented above, the $\mathrm{CO}_{2}$ emissions have increasing trend in transport sector. What is opposite of ambitions of $\mathrm{CO}_{2}$ reduction targets.

There are many ways how to reduce $\mathrm{CO}_{2}$ in international road and rail freight transport. They could be divided to:

1. International road freight transport: - technical measures and - non-technical measures

2. Measures for $\mathrm{CO}_{2}$ reduction in international rail freight transport

3. General measures for $\mathrm{CO}_{2}$ reduction in international surface freight transport where belongs: - biofuels and other alternative fuels

- measures aimed at volume reduction and modal shift 


\subsection{International road freight transport and measures how to improve efficiency}

It is obviously that fuel costs are a significant part of the operating costs of heavy duty vehicles. This is main reason why traditionally efficiency improvement takes important part in engine and vehicle developments. As a consequence, the potential of improvement is limited, mainly in long-distance transport sector.

The main technical options for improving energy-efficiency in heavy duty vehicles are:

- Low rolling resistance tyres $(\approx 6 \%)$.

- Engine improvements $(\approx 5 \%)$.

- Reduction of air resistance $(\approx 6 \%)$.

- Increased weight limit to 44 or 60 tonne $(\approx 9-20 \%)$.

- Lightweight construction $(\approx 7 \%)$.

- Hybrid propulsion for city buses and distribution trucks $(\approx 15 \%)$. [15]

The percentages between brackets are fuel consumption reduction values for new vehicles.

To the main non-technical options for improving energy efficiency belong:

- eco-driving (for example to keep low engine rpm by early shifting gear during acceleration or continual and expectable driving),

- traffic measures (synchronization of traffic lights, lower speed limits on congested highways),

- better logistics - better organization of lines, better cooperation of transport operators, full payload of vehicles....

\subsection{Measures for $\mathrm{CO}_{2}$ reduction in international rail freight transport}

Efficiency improvement of diesel trains has not very high policy priority as they are responsible only for $0,5 \%$ of the EU- $28 \mathrm{CO}_{2}$ emissions. Also, the efficiency of modern electric trains greatly improved thanks to use of power electronic and regenerative braking.

Plus, there are other possibilities for improvements of energy efficiency as for example:

- improvement of aerodynamics,

- decreasing friction,

- mass reduction,

- speed optimalization,

- braking reducing...etc.

\subsection{General measures for $\mathrm{CO}_{2}$ reduction in international surface freight transport}

Although in the transfer sector oil is still dominant energy source, in the long term, because of oil possible exhaustibility, there is huge pressure for using alternative sustainable sources and nuclear power.

Biofuels have big future although they still contribute to climate changes because of greenhouse gas emissions. Biofuels is still perspective and interesting field as nowadays are developed new biofuels (also called second-generation biofuels) which are expected to achieve a reduction of $80-90 \%$ of greenhouse gas. However, biofuels will have to be developed further.

Negative side of biofuels is price - most biofuels are more expensive then fossil fuels. Second negative effect is on biodiversity. 
After biofuels follow hydrogen and electricity which play interesting role in the energy supply of the transport sector from the long point of view. Important is to say, that both are not energy sources only energy carriers.

Last measure is to try reducing the expected growth of transport volume. First step could be shift of transport volumes to the more efficient modes of transport if it is possible. So requirements for greener logistics are still very topical.

\section{Conclusion}

Dominate cargo transport via roads has too many negative effects. Because of it there is strong public pressure to shift the cargo from roads to rails and rivers. This also makes logistics greener. To support intermodal freight transport is also one of the main strategies of EU. But higher trade internationalization made also logistics more global. Now it is clear that successful implementation of green logistics is not possible without cooperation of global and local environmental governance. On the other hand, it is hard to solve conflict between economic interests of logistics and the negative transport impact to the environment. Firstly, it is mostly political topic as without governments green logistics cannot be implementing successfully and secondly strong institutional factors, which are responsible for monitoring and enforcing environmental sustainability will most effectively realize green logistics. Because of it, further governments' interventions show to be necessary for promoting and intervention greater environmental regulation.

As to individual logistics companies, they must to find a match between profitability and environmental considerations. Many companies try to adopt green measures. From this point of view railway transport sounds as good solution as it is backbone of EU freight transport system. It is also good answer for world environmental reality which is requiring developing it even more. Main reason is, that railway freight transport is not only sustainable but also more environmental friendly than road transport.

\section{Acknowledgement}

The present contribution has been prepared with direct support of Ministry of Education, Science, Research and Sport of Slovak Republic through the projects KEGA 007TUKE4/2018 and VEGA 1/0795/19.

\section{References}

[1] Knörr, W.: EcoTransIT: Ecological transport information tool - Environmental methodology and data. Technical report, Institut fur Energie (ifeu) und Umweldforschung Heidelberg GmbH, (2008). Available at http://www.ecotransit.org/download/ecotransit_background_report.pdf

[2] Coe, E.: Average carbon dioxide emissions resulting from gasoline and diesel fuel. Technical report, United States Environmental Protection Agency, (2005). Available at http://www.epa.gov/otaq/climate/420f05001.pdf

[3] Bauer, J., Bekta, T., Crainic, T.G.: Minimizing Greenhouse Gas Emissions in Intermodal Freight Transport: An Application to Rail Service Design. Journal of the operational research society, Vol. 61, Issue: 3, pp. 530-542 (2010) 
[4] Llano, C., Pérez-Balsalobre, S., Pérez-García, J.: Greenhouse Gas Emissions from Intra-National Freight Transport: Measurement and Scenarios for Greater Sustainability in Spain. Sustainability. Vol. 10, Issue 7, pp. 1-33 (2018)

[5] Eurostat [online] [25.05.2018] Available at internet: http://ec.europa.eu/eurostat/statisticsexplained/index.php/Greenhouse gas emission statistics - emission inventories

[6] Petru, J. et al.: Influence of cutting parameters on heat-affected zone after laser cutting, Technical Gazette, 20/2, 225-230 (2013)

[7] Monkova, K.; Monka, P.: Newly Developed Software Application for Multiple Access Process Planning, Advances in mechanical engineering, Article Number 539071, (2014)

[8] Misik, L. et al.: Side milling factors analysis affecting the surface irregularities of high-grade steel E295, Technical Gazette, 15/2, 19-23 (2008)

[9] Eurostat [online] [25.05.2018] Available at internet: http://ec.europa.eu/eurostat/statisticsexplained/index.php/Freight_transport_statistics___modal_split

[10] Monkova, K. et al.: Inverse Processing of Undefined Complex Shape Parts from Structural High Alloyed Tool Steel, Advances in Mechanical Engineering, article num. 478748, (2014)

[11] Hricová, R.: Some aspects of freight transport in Europe. ICMEM 2010: Manufacturing Engineering and Management 2010: 1st International Scientific Conference: Prešov, Slovak republic, pp. 166-169 (2010)

[12] Radvanska, A. et al.: Rationalization of manufacturing of plastic injection moulds by abrasive waterjet, Tehnicki Vjesnik 22 (2), pp. 521-525 (2015)

[13] Hreha, P. et al.: Investigation of sandwich material surface created by abrasive water jet (AWJ) via vibration emission, Metalurgija, 53/1, 29-32 (2014)

[14] Eurostat [online] [26.05.2018] Available at internet: http://ec.europa.eu/eurostat/statisticsexplained/index.php/Climate change - driving forces

[15] Smokers, R., Kampman, B.: Energy Efficiency in the Transport Sector-Discussion paper prepared for the PEEREA Working Group on Energy Efficiency and Related Environmental Aspects, CE Delft, Delft, the Netherlands (2006) 